\title{
Red Blood Cell Transfusion in a Neonatal Tertiary Care Center: A Moroccan Study
}

\author{
Laila Essabar1, Houria Knouni', Amina Barkat ${ }^{2}$ \\ ${ }^{1}$ Department of Medicine and Neonatal Resuscitation, National Center for Neonatology and Nutrition, Rabat, Morocco \\ ${ }^{2}$ Mother and Child Health and Nutrition Research Team, Faculty of Medicine and Pharmacy of Rabat, Med V University, Rabat, Morocco \\ Email: barakatamina@hotmail.fr
}

How to cite this paper: Essabar, L., Knouni, H. and Barkat, A. (2016) Red Blood Cell Transfusion in a Neonatal Tertiary Care Center: A Moroccan Study. Journal of Biosciences and Medicines, 4, 54-60. http://dx.doi.org/10.4236/jbm.2016.49006

Received: August 26, 2016

Accepted: September 27, 2016

Published: September 30, 2016

Copyright $\odot 2016$ by authors and Scientific Research Publishing Inc. This work is licensed under the Creative Commons Attribution International License (CC BY 4.0).

http://creativecommons.org/licenses/by/4.0/ (c) (i) Open Access

\begin{abstract}
Background: Red Blood Cell (RBC) transfusion is a common therapy in neonatal practice and data from different international neonatal centers are available, however, there is paucity of Moroccan data regarding blood components usage. We aim to study trends and outcomes of RBC transfusions in our department and emphasize the need for transfusion guidelines. Material and method: This retrospective study was performed in a Moroccan tertiary neonatal intensive care center. The records of all neonates admitted from January 2015 to March 2016 were screened for RBC usage and indications. The data were statistically analyzed by using Microsoft Excel ${ }^{\mathrm{TM}}$ software. Results: A total of 60 neonates received $77 \mathrm{RBC}$ transfusions. Postnatal age at transfusion ranged from 1 to 30 days with an average of 13 days, and $30 \%$ of our patients were aged $\geq 21$ days. RBC Transfusion was given once in 48 patients (80\%), twice in 8 patients $(13.3 \%)$ and $\geq$ thrice in 4 patients $(6.7 \%)$. More than one type of blood components was needed in 23 (38\%) neonates. $70 \%$ of patients were critically ill, $60 \%$ were born before 37 weeks' gestation and $57 \%$ were small for gestational age. Mean hemoglobin at the time of transfusion of RBC was $8.59 \mathrm{~g} / \mathrm{dl}(2-11.6 \mathrm{~g} / \mathrm{dl})$. Sepsis and anemia with mechanical ventilation for severe respiratory illness were the commonest indications. All gestational ages were considered, and mortality was noted in $66 \%$ of our cases and worsening in $13 \% ; 21 \%$ of the infants showed improvement. Conclusion: Judicious implementation of guidelines for RBC transfusions would decrease their inappropriate use.
\end{abstract}

\section{Keywords}

Newborn, Red Blood Cell, Transfusion, Neonates

\section{Introduction}

Red Blood Cell (RBC) transfusion is a common intervention in neonates, especially 
preterm and critically ill babies. Historically, transfusion practices have varied among clinicians and different centers given the lack of evidence-based neonatal transfusion guidelines. However, a growing body of research has fortunately begun to focus on issues related to neonatal transfusion.

$\mathrm{RBC}$ transfusion in neonates may be lifesaving, however, blood products are a costly and limited resource and adverse effects are being increasingly recognized following neonatal transfusions [1]. These include introduction of donor antigens in the recipient, transfusion reactions or exposure to various transfusion transmitted diseases, Graft-versus-Host disease, transfusion-related acute lung injury, transfusion-associated circulatory overload, toxic effects of anticoagulants, risk of necrotising enterocolitis, and extension of intraventricular haemorrhage [2]. Thus, the indications for ordering red blood cells must be fully justified to avoid misuse or overuse of this precious resource. Although better guidelines have been suggested and put into practice and international data from different centers are now available, there is paucity of Moroccan data.

Our purpose was to study trends and outcomes of red cell transfusions in our department and emphasize the urgent need of forming guidelines and policies for red blood cell transfusions in neonates.

\section{Materials \& Methods}

This retrospective study was performed in a Moroccan tertiary neonatal intensive care center. The records of all neonates admitted from January 2015 to March 2016 were screened for RBC usage and their indications. All consecutive neonates ( 0 to 28 days of life) admitted during the study period in our center that underwent red blood cell transfusion were eligible for study enrollment. Some transfusions occurring after 28 days (in neonates not discharged until later) have been included. Transfusion may have occurred in one or more admissions; each neonate was counted once.

All the inborn and outborn of at least 24 weeks' gestation or $500 \mathrm{~g}$ birth weight, and all babies admitted with surgical causes were included. The neonates, who stayed in our department for less than twenty-four hours or received any blood component prior to admission, were excluded from the study. Neonates with missing gestational age or incomplete transfusion data were excluded as well.

The following baseline data were collected: maternal age, gestational age, delivery mode, postnatal age at transfusion, septic state, severity of illness and need for ventilatory and inotropic support. Birth weight was used to calculate birth weight percentile using LEROY-LEFORT curves.

Gestational age was defined as the best estimate based on early ultrasound, obstetric history, and examination followed by pediatric estimate in that order.

We also collected data about transfusion which included pre-transfusion and posttransfusion hemoglobin, number of transfusions, volume and number of red-cell units per transfused patient, indication for transfusion as well as the use of other blood components (fresh-frozen plasma, platelets and albumin). Red cell transfusions were administered in accordance with a formula that accounted for the patient's weight and the 
average hemoglobin concentration in red-cell units.

Clinical outcomes were collected including the length of stay in hospital, mortality, worsening or organ dysfunctions, adverse events and reactions.

Data Analysis: Data were exported to a Microsoft Excel file. The characteristics of study infants were analyzed by descriptive statistics. Comparison between pre-transfusion and post-transfusion hemoglobin was performed using student test (paired t-tests). Descriptive results are expressed as numbers and proportions (\%). A p-value < 0.05 was considered significant.

\section{Results}

During the study period, a total of 60 neonates received 77 RBC transfusions. The baseline variables of the neonates included in the study are reported in Table 1. Postnatal

Table 1. Baseline variables.

\begin{tabular}{|c|c|}
\hline Variable & Percentage \\
\hline \multicolumn{2}{|l|}{ Maternal age } \\
\hline$<20$ & $6.6 \%$ \\
\hline $20-34$ & $70 \%$ \\
\hline$\geq 35$ & $23 \%$ \\
\hline \multicolumn{2}{|l|}{ Baby gender } \\
\hline Male & $48 \%$ \\
\hline Female & $62 \%$ \\
\hline Multiple birth & $8.3 \%$ \\
\hline \multicolumn{2}{|l|}{ GA } \\
\hline$\leq 31$ & $10 \%$ \\
\hline $32-34$ & $26.6 \%$ \\
\hline $35-36$ & $23.4 \%$ \\
\hline $37-41$ & $33.3 \%$ \\
\hline $42+$ & $6.7 \%$ \\
\hline \multicolumn{2}{|l|}{ Mode of delivery } \\
\hline Vaginal delivery & $75 \%$ \\
\hline Cesarean-section & $25 \%$ \\
\hline \multicolumn{2}{|l|}{ Apgar } \\
\hline$<4$ at $1 \mathrm{~min}$ & $3.3 \%$ \\
\hline$<7$ at $5 \mathrm{~min}$ & $8.3 \%$ \\
\hline \multicolumn{2}{|l|}{ Birth weight } \\
\hline SGA $-<10$ th centile & $57 \%$ \\
\hline AGA & $40 \%$ \\
\hline LGA $\rightarrow$ 90th & $3 \%$ \\
\hline
\end{tabular}

GA: gestational age; SGA: small for GA; AGA: appropriate for GA; LGA: large for GA. 
age at transfusion ranged from 1 to 30 days with an average of 13 days, while $30 \%$ of our patients were aged $\geq 21$ days. RBC transfusion was given once in 48 patients (80\%), twice in 8 patients $(13.3 \%)$ and $\geq$ thrice in 4 patients $(6.7 \%)$.

More than one type of blood components was needed in 23 (38\%) neonates. Fresh frozen plasma was given in all of them and platelet in $21 \%$ of those cases. 2 patients underwent albumin transfusion.

Transfusions were predominantly given to neonates who were critically ill (70\%) with ventilatory and inotropic support. $28 \%$ of transfusions were given in non-intensive care environment.

RBC transfusion was slightly more common among neonates who were small for gestational age (57\%) and preterm gestations (60\%).

Table 2 describes the indications for which the RBC transfusions were administered. Mean hemoglobin at the time of transfusion of RBC was $8.59 \mathrm{~g} / \mathrm{dl}(2-11.6 \mathrm{~g} / \mathrm{dl})$.

Table 3 compares the hemoglobin of the infant pre- and post-transfusion according to the gestational age, $\mathrm{RBC}$ response was statistically significant in the three patient groups.

All gestational ages considered, mortality was noted in $66 \%$ of our cases and worsening in $13 \% ; 21 \%$ of the infants showed improvement after increase in hemoglobin

Table 2. Indications of RBC transfusion.

\begin{tabular}{lc}
\hline \multicolumn{1}{c}{ Indication } & Percentage \\
\hline Sepsis & $36 \%$ \\
Congenital anomaly requiring surgery & $15 \%$ \\
Haemolytic disorder & $5 \%$ \\
Anemia with mechanical ventilation for severe respiratory illness & $17 \%$ \\
Fetal blood loss & \\
Twin to twin transfusion syndrome & $3.4 \%$ \\
Fetal bleeding & $1.7 \%$ \\
Bleeding of various etiologies & $10 \%$ \\
Asymptomtic infant with severe anemia & $8.4 \%$ \\
Others & $3.4 \%$ \\
\hline
\end{tabular}

Table 3. Comparison of pre-transfusion and post transfusion hemoglobin according to gestation age.

\begin{tabular}{cccc}
\hline Gestational Age & $\begin{array}{c}\text { Mean Pre-Transfusion } \\
\text { Hemoglobin }\end{array}$ & $\begin{array}{c}\text { Mean Post Transfusion } \\
\text { Hemoglobin }\end{array}$ & p-Value \\
\hline 28 - 34 weeks & 8.8 & 10.9 & $<0.01$ \\
35 - 36 weeks & 8.6 & 12.08 & $<0.01$ \\
$\geq 37$ weeks & 8.38 & 11.2 & $<0.01$ \\
\hline
\end{tabular}


concentrations. No transfusion reaction was seen in any patient during the whole study period.

\section{Discussion}

Although transfusion rate were lower in mature neonates in our study, a substantial proportion (40\%) of neonates receiving transfusions were born $\geq 37$ weeks' gestation.

In contrast with previous studies [1] [3], 83\% (30/36) of preterm babies in our study were born after 32 weeks' gestation, this finding may be explained by the small number of patients aged $\leq 31$ weeks' gestation eligible for the study, a larger sample study is therefore needed to better study transfusion outcomes in this age group.

More than half of our patients (57\%) are small for gestational age, and our results are similar to those shown previously by Bowen et al. in their study where they demonstrated that higher crude transfusion rates were seen in this category of neonates [1].

Furthermore, very low birth weight and, in particular, extremely low birth weight babies form a class of neonates more frequently administered transfusion therapy and, precisely because of the extreme immaturity of their various organs and systems, may be predisposed to more side effects of the blood transfusion [4].

Among the indications for RBC transfusion, sepsis and anemia with mechanical ventilation for severe respiratory illness were the commonest indications. This may be explained by the high percentage of critically ill patients (70\%) and preterm babies (60\%) in our study. However, Avneet et al. similarly reported that sepsis was the most common cause or associated factor in RBC transfusion especially in patients requiring multiple transfusions [5].

Transfusion for heamolytic disorder was indicated in $5 \%$ of our patients, none of them underwent exchange. This is consistent with the study of Bowen JR and al. [1] who reported a significant reduction of the need for exchange transfusions, this is due to the decrease of incidence of haemolytic disease with the widespread use of anti-D immunoglobulin [6] [7], the more effective phototherapy devices, the use of intravenous immune globulin in neonates approaching exchange transfusion levels and the introduction of in utero transfusions for severe fetal anaemia, this latter is not available in our center.

Fifteen percent of cases in our study underwent surgery for congenital anomaly; these patients remain a group with high transfusion requirements [8], given their low circulating blood volume and the major consequences of blood loss on their tissue perfusion.

Despite the expanding body of research on the RBC transfusion therapies, a consensus is still to be made on various threshold values for transfusion [5] [9]. In our study, hemoglobin levels at the time of transfusion ranged from 2 to $11.6 \mathrm{~g} / \mathrm{dl}$ with an average of $8.59 \mathrm{~g} / \mathrm{dl}$, higher thresholds were noted in critically ill patients and preterm babies with respiratory support.

The high rate of mortality observed in the current study (66\%) may be explained by the high proportion of critically ill patients (70\%), some authors [10] discussed the pos- 
sibility of an underlying cause-effect relationship between RBC transfusion and high mortality rates. However, according to previous findings from randomized controlled trials [11] and several retrospective studies, RBC transfusion in infants is not associated with mortality [12].

Limitations of this study are the small sample size, retrospective nature, single center data and heterogeneity of the studied population in terms of gestational age and nature of disease. A prospective stratified study with fairly large sample size will help us to better analyze the RBC transfusion outcomes.

\section{Conclusion}

Red blood cell transfusion is commonly used in neonatal practice. Sepsis remains the foremost etiological factor for transfusion, especially if there is a need for multiple transfusions. Answers to queries like optimal transfusion threshold and new practices to prevent transfusion-transmitted infections are still not clear, but further research is still needed to fill the gaps.

\section{Conflicts of Interest}

All the authors have no conflicts of interest to disclose.

\section{References}

[1] Bowen, J.R., Patterson, J.A., Roberts, C.L., Isbister, J.P., Irving, D.O. and Ford, J.B. (2015) Red Cell and Platelet Transfusions in Neonates: A Population-Based Study. Archives of Disease in Childhood-Fetal and Neonatal Edition, 100, F411-F415.

[2] Quinn, K., Quinn, M., Moreno, C., Soundar, E., Teruya, J. and Hui, S.K. (2015) Neonatal Transfusion Models to Determine the Impact of Using Fresh Red Blood Cells on Inventory and Exposure. Blood Transfusion, 13, 595-599.

[3] Mercer, J.S., Vohr, B.R., McGrath, M.M., Padbury, J.F., Wallach, M. and Oh, W. (2006) Delayed Cord Clamping in Very Preterm Infants Reduces the Incidence of Intraventricular Hemorrhage and Late-Onset Sepsis: A Randomized, Controlled Trial. Pediatrics, 117, 1235-1242. http://dx.doi.org/10.1542/peds.2005-1706

[4] Girelli, G., Antoncecchi, S., Casadei, A.M., et al. (2015) Recommendations for Transfusion Therapy in Neonatology. Blood Transfusion, 13, 484-497.

[5] Kaur, A., Dhir, S.K., Kaur, D., Gupta, M. and Batta, M. (2015) Blood Component Therapy in Neonates in a Neonatal Intensive Care Unit of Northern India. Clinical Epidemiology and Global Health, 3, S38-S42. http://dx.doi.org/10.1016/j.cegh.2015.10.011

[6] Steiner, L.A., Bizzarro, M.J., Ehrenkranz, R.A. and Gallagher, P.G. (2007) A Decline in the Frequency of Neonatal Exchange Transfusions and Its Effect on Exchange-Related Morbidity and Mortality. Pediatrics, 120, 27-32. http://dx.doi.org/10.1542/peds.2006-2910

[7] NSW Health. (2006) NSW Health Policy Directive Rh D Immunoglobulin (Anti-D) PD 2006_074.

[8] Heart Kids (2009) Children with Heart Conditions-A Booklet for Parents of Children with Heart Conditions. Heart Kids, Pennant Hills.

[9] Nickel, R.S. and Josephson, C.D. (2015) Neonatal Transfusion Medicine: Five Major Unanswered Research Questions for the Twenty-First Century. Clinics in Perinatology, 42, 
499-513. http://dx.doi.org/10.1016/j.clp.2015.04.006

[10] Keir, A., Aziz, K., McMillan, D., et al. (2015) Red Blood Cell Transfusions at 21 Days of Age or Older in Previously Transfusion-Naive Very Preterm Infants: Association with Neonatal Outcomes. American Journal of Perinatology, 32, 1139-1144. http://dx.doi.org/10.1055/s-0035-1549295

[11] Whyte, R. and Kirpalani, H. (2011) Low versus High Haemoglobin Concentration Threshold for Blood Transfusion for Preventing Morbidity and Mortality in Very Low Birth Weight Infants. Cochrane Database Syst Rev, 11, CD000512. http://dx.doi.org/10.1002/14651858.cd000512.pub2

[12] Maier, R.F., Sonntag, J., Walka, M.M., Liu, G., Metze, B.C. and Obladen, M. (2000) Changing Practices of Red Blood Cell Transfusions in Infants with Birth Weights Less than 1000 g. The Journal of Pediatrics, 136, 220-224. http://dx.doi.org/10.1016/S0022-3476(00)70105-3

Submit or recommend next manuscript to SCIRP and we will provide best service for you:

Accepting pre-submission inquiries through Email, Facebook, LinkedIn, Twitter, etc. A wide selection of journals (inclusive of 9 subjects, more than 200 journals)

Providing 24-hour high-quality service User-friendly online submission system

Fair and swift peer-review system Efficient typesetting and proofreading procedure

Display of the result of downloads and visits, as well as the number of cited articles Maximum dissemination of your research work

Submit your manuscript at: http://papersubmission.scirp.org/

Or contact jbm@scirp.org 